\title{
Dialektika antara Komunitas Mata Kita dan Narasi tv dalam Perpektif Strukturasi Giddens
}

\author{
Risky Wahyudi \\ Prodi Kajian Budaya dan Media, Universitas Gadjah Mada, Yogyakarta, Indonesia \\ email: riskywahyudi12394@gmail.com
}

\begin{abstract}
This article seeks to address the dialectical relationship between Najwa Shihab fans as a member of Mata Kita community with the TV Narration. In fact, it's a streaming television set up by official Najwa Shihab. In addition, in term of explaining the dialectics of fans and TV Narration, this study will uses Anthony Giddens's structuration theory. So that, the method used is virtual ethnography. Arguably, the author observed in the Narrative TV virtual community, and continued with an interview. Finally, this study found that the relationship between structure, the rules created by TV Narrative and agents, namely Mata Kita community on which in dialectical feature. It seem that the Mata Kita community is not passive audience. Instead, they are constantly negotiating the rules made by TV Narrative. The negotiations then resulted in more flexible rules. Furthermore, it's highly recommends the necessary of the structure represented by media institutions to view the public as an active agent, so that the determination of the program should be more participatory.
\end{abstract}

Keywords: Audience, Community, Structure and Agent.

\begin{abstract}
Abstrak. Penelitian ini bertujuan menjelaskan relasi dialektis antara penggemar Najwa Shihab yang tergabung ke dalam komunitas Mata Kita dengan Narasi tv. Narasi tv adalah televisi streaming yang dibentuk oleh ofisial Najwa Shihab. Untuk menjelaskan dialektika penggemar dan Narasi tv tersebut, penelitian ini menggunakan teori strukturasi Anthony Giddens. Metode yang digunakan adalah etnografi virtual. Peneliti melakukan pengamatan dalam komunitas virtual Narasi tv, dan kemudian dilanjutkan dengan wawancara. Penelitian ini menemukan bahwa hubungan antara struktur, yakni aturan-aturan yang diciptakan oleh Narasi t $v$ dengan agen, yakni komunitas Mata kita bersifat dialektis. Penelitian ini menunjukkan bahwa komunitas Mata Kita bukanlah penonton pasif. Sebaliknya, mereka terus-menerus melakukan negosiasi terhadap aturan yang dibuat oleh Narasi tv. Negosiasi itu kemudian menghasilkan aturan yang lebih fleksibel. Penelitian ini merekomendasikan pentingnya struktur yang diwakili oleh institusi media untuk melihat khalayak sebagai agen yang aktif sehingga penentuan program mestinya bisa lebih partisipatif.
\end{abstract}

Kata Kunci: Khalayak, Komunitas, Struktur dan Agen 


\section{PENDAHULUAN}

Nama Najwa Shihab populer di kalangan anak muda Indonesia. Perempuan yang bekerja sebagai presenter dalam program acara televisi ini dikenal tegas, lugas, dan berani menyampaikan gagasannya. Ia juga mendapatkan penghargaan sebagai sosok inspiratif pada pagelaran Perempuan Bintang Awards 2018 dari kategori Bintang Profesi Terbaik (Tempo.co, 2018) Najwa Shihab mulai dikenal masyarakat melalui program acara televisi "Mata Najwa" yang disiarkan oleh Metro TV sejak 2009. Program acara tersebut diminati khalayak karena sering membahas isu yang sedang hangat di Indonesia, dan mampu menghadirkan narasumber kunci dalam pembahasan isu tersebut. Sebagai presenter, Najwa Shihab berhasil menarik perhatian khalayak dengan pertanyaan kritis, berani, dan tajam. Ketika beredar isu episode terakhir program acara "Mata Najwa", setelah episode wawancara eksklusif dengan Novel Baswedan pada 8 Agustus 2017, khalayak heboh. Khalayak pada kolom komentar postingan akun instagram @najwashihab memberikan apresiasi terhadap keputusan Najwa Shihab, dan tetap memberikan support kepadanya (https://www.instagram. com Lp/BYbByR8hIta/., 2020) Sampai akhirnya, program "Mata Najwa" tayang sebagai episode terakhir di stasiun televisi Metro TV pada 30 Agustus 2017 dengan judul "Catatan Tanpa Titik". Ketika sudah tidak aktif di televisi, Najwa Shihab melanjutkan aktivitasnya dengan membuat program acara talkshow di akun YouTube miliknya yang berjudul "Catatan Najwa". Pada 10 Januari 2018, program "Mata Najwa" kembali tayang di layar kaca dengan stasisun televisi berbeda, yaitu Trans 7 . Selain itu juga, Najwa Shihab bersama rekan-rekannya mendirikan platform televisi berbasis daring yang bernama Narasi tv (https://www.Narasi .tv/, 2018)
Dalam saluran ini pula, ditayangkan acara Mata Najwa secara Streaming.

Dalam perkembangannya, Narasi tv membentuk komunitas Mata Kita. Dalam postingan Instagram yang diunggah pada 24 Mei 2018, Najwa Shihab mengklaim bahwa komunitas Mata Kita sebagai komunitas resmi penonton tayangan program acara televisi "Mata Najwa" (Https://www.instagram.com/p/BjJpclIFreH/, 2018b).

Hingga kini, komunitas Mata Kita sudah memiliki sekitar 100.00o anggota yang tersebar di 20 cabang di seluruh Indonesia, bahkan hingga ke Hongkong (per 4 Desember 2018). Kegiatan rutin yang biasanya mereka lakukan adalah kopi darat, menggelar event, diskusi, nonton bareng, social movement, hingga membuat program yang akan ditampilkan di platform Narasi tv. Meskipun begitu, Narasi tv juga melirik fenomena penggemar Najwa Shihab, dan menjadikan komunitas ini sebagai jalur fastrack agar lebih dekat dengan tokoh yang diidolakannya tersebut. Di luar itu, mereka dituntut produktif, dan dalam beberapa hal dilibatkan untuk berpartisipasi dalam kegiatan yang digelar Narasi tv. Dengan demikian, berbeda dengan fenomena fandom pada umumnya, dalam konteks komunitas Mata Kita, penonton tidak lagi hadir sebagai dirinya sendiri. Mereka "dikendalikan" oleh media dalam mewujudkan ekspresi kecintaan terhadap idolanya. Ini karena mereka harus mengikuti struktur yang ditawarkan oleh Narasi tv untuk bisa mewujudkan ekspresi fandom-nya.

Penelitian ini melihat relasi sosial yang terbentuk antara Komunitas Mata Kita, Najwa Shihab, dan Narasi tv melalui perspektif ekonomi politik komunikasi. Vincent Mosco memberikan tiga tawaran konsep kunci ketika hendak melakukan 
penelitian ekonomi politik, yaitu commodification, spatialization dan structuration (Mosco, 2009). Studi ini menggunakan pendekatan strukturasi untuk melihat bagaimana hubungan sosial antara khalayak dan Narasi tv. Secara khusus, penelitian ini melihat bagaimana dialektika antara struktur dan agen di balik terbentuknya komunitas Mata Kita. Kajian ini penting karena ketegangan antara struktur dan agen telah menjadi isu utama dalam ilmu sosial, dan Anthony Giddens kiranya telah memecahkan dilema ini (lihat Nugroho dkk, 2015). Dalam pandangan Giddens, antara struktur dan agensi terjadi proses dialektis yang saling mempengaruhi.

Giddens (1986) menempatkan struktur dan agen sebagai "dualitas". Ini karena Giddens membayangkan bahwa antara struktur dan agen bersifat dialektik. Struktur terdiri atas aturan (rules) dan sumber daya (resources). Struktur dipahami melalui dua cara, yaitu sebagai hasil (outcome) dan juga sarana (medium) praktik sosial.

Relasi dualitas antara agen mengandung kesadaran Giddennian, yakni discursive consciousness dan practical consciousness. Practical consciousness berkaitan dengan bagaimana agen dapat menjelaskan secara diskursif tentang niat dan alasan mereka ketika bertindak. Ini berbeda dengan practical consciousness di mana tindakan diterima begitu saja. Namun, Giddens tidak memisahkan discoursive consciousness dan practical consciousness secara kaku atau tertutup rapat karena sejatinya di antara discoursive consciousness dan practical consciousness tidak memiliki pembatas: hanya ada perbedaan antara apa yang bisa dikatakan dan apa yang dilakukan secara khas. Hal ini dilatarbelakangi oleh banyak aspek dari sosialisasi agen dan pengalaman belajar (Giddens, 1986).
Mosco (2009) memberi catatan bahwa teori strukturasi Giddens cenderung menonjolkan agensi, yang berdampak memiliki konsepsi struktur terbatas pada seperangkat aturan operasi (rules) dan sumber daya (resource) yang digunakan agen untuk memenuhi kebutuhan mereka. Mosco mengemukakan bahwa strukturasi masih belum konsisten. Meskipun begitu, Mosco mempertahankan gagasan umum Giddens terkait dualitas struktur dan agen, lalu mengelaborasikannya dengan memberi bobot yang lebih besar terhadap kekuasaan dan juga penggabungan struktur ke dalam pendekatan kritis terhadap analisis sosial (Mosco, 2009). Penjelasan sederhananya: strukturasi adalah pintu masuk untuk memeriksa konstitusi yang saling bergantungan dari struktur dan agen dalam ekonomi politik. Ini adalah titik awal untuk memperluas konsepsi kekuasaan dan memberikan kesempatan untuk memahami bentuk-bentuk yang diambil dari hubungan sosial dalam ekonomi politik (Mosco, 2009). Dalam hal ini, posisi media bukan dilihat sebagai alat untuk memenuhi kepentingan negara atau pihak yang dominan, melainkan sebagai sebuah praktik sosial. Media senantiasa berada dalam situasi dinamis, cair, dan selalu dalam proses yang pada situasi tertentu bisa memproduksi artikulasi negara, tapi di situasi yang lain bisa menciptakan resistensi (Ashaf \& Firman., 2006).

Pembacaan atas strukturasi dapat dikerucutkan lagi ke arah ekonomi politik pemilik media dalam menentukan isi media (Haryanto, 2014). Bahkan untuk menjamin keberlangsungan sistem media juga membutuhkan struktur, seperti strukturasi komunikasi internal pada praktik media relations (Pratama \& Putra, 2018). Tidak hanya itu, relasi antara media dengan khalayak juga bisa diciptakan struktur konsumen, meskipun pada 
akhirnya dapat berkembang secara dinamis (Junaedi et al., 2017).

Penelitian ini memasuki ranah dialektika antara media berbasis streaming dengan khalayak berbasis penggemar. Oleh karena itu, fenomena perkembangan televisi streaming perlu disinggung karena Narasi tv merupakan bagian itu. Tidak bisa dipungkiri, kehadiran media baru (internet) mempengaruhi relasi antara khalayak dan media. Namun, perkembangan televisi ini tidak bersifat linear dan universal di berbagai konteks budaya karena televisi tidak hanya dibentuk semata oleh faktor ekonomi dan teknologi, tetapi juga ditentukan oleh faktor politik dan budaya (Enli \& Syvertsen, 2016). Oleh karena itu, ketika hendak mendiskusikan fenomena televisi streaming, perlu dilihat potret dinamikanya di Indonesia. Kemunculan internet membuat khalayak tidak lagi berjarak dengan media, melainkan diwadahi untuk lebih dekat dengan media. Efek kehadiran internet menimbulkan pergeseran ruang dan waktu dalam menonton televisi. Menonton tayangan program acara televisi kini tidak lagi semata menggunakan pesawat televisi, melainkan bisa diakses melalui gadget.

Konsumsi media berdasarkan pada kebutuhan perorangan dipengaruhi oleh lingkungan sosialnya. Ini karena penonton televisi streaming berkontestasi dengan mobilitas waktu, kapital, dan gaya hidup di lingkungan mereka. Bahkan ketika menyorot generasi milenial, mereka adalah tipikal yang jarang duduk berjam-jam di depan televisi untuk menonton sebuah acara. Terminologi 'social engagement (keterlibatan sosial)' menjadi tepat untuk menggambarkan bagaimana khalayak sekarang memiliki pengalaman menonton televisi dengan menggunakan platform media sosial yang beragam (Permana, Rangga, Saptya et al., 2019) (Imran, 2016)
(A.S, 2017) (Abdullah et al., 2018) (Guo, 2018).

Banyak penelitian seputar fandom telah dilakukan seperti pertemuan fandom -baik tatap muka maupun secara virtualdunia fans yang selalu dihadapkan dengan hirarki kelompok, minoritas, dan konflik layaknya sebuah organisasi sosial (Pearson, 2010). Meskipun begitu, peran fans mampu mengatasi hambatan dan jangkauan politik. Dengan kata lain, budaya ini mampu mencapai berbagai kalangan konsumen bahkan mereka yang terpinggirkan (Otmazgin et al., 2013). Selain itu, perlu disadari bahwa di balik eksistensi fandom, juga ada eksistensi poacher yang terus mengalami perkembangan (Bennett, 2014).

Kehadiran fandom juga bisa dijadikan sebagai target sasaran pasar (Silva et al., 2017). Bahkan, fans juga bisa terkonstruksi dalam lingkup pemasaran industri budaya (Mulyana et al., 2019). Sebuah fenomena fandom disesuaikan dan dialami dalam kehidupan sehari-harinya (Jeong et al., 2017).

Biasanya, komunitas penggemar itu berangkat dari khalayak media. Ini berkebalikan dengan komunitas Mata Kita yang malah dibentuk media. Pada akhirnya, kehadiran khalayak bisa dikondisikan dan dikoordinasikan dalam satu forum. Mereka bisa saling berinteraksi antar-sesama khalayak, dan memiliki peluang untuk berinteraksi dengan pihak media. Bahkan, mereka berkesempatan untuk bisa menggarap projek bersama . Maka dari itu, tawaran kebaruan penelitian ini ialah mengkaji bagaimana media dalam hal ini televisi berbasis streamingmencoba untuk meng-create khalayak dan menstrukturkan mereka. Hal yang hendak dikaji lebih lanjut ialah menganalisis dialektika antara Komunitas Mata Kita dengan Narasi tv melengkapi kajian strukturasi media dalam konteks 
Indonesia seperti telah dikerjakan Junaedi et al., (2017) dan Nugroho et al., (2015). Tujuan penelitian ini adalah mendialogkan fenomena ekonomi politik media dengan menggunakan pendekatan strukturasi.

\section{METODE}

Penelitian ini menggunakan metode etnografi virtual (netnografi). Ketika memposisikan diri sebagai seorang etnografer virtual, peneliti tidak berfokus terhadap apa yang luar biasa tentang mereka, melainkan berfokus pada apa yang biasa tentang mereka (Boellstorff et al., 2012). Penelitian ini dilakukan di penghujung akhir 2018. Sumber data didapatkan melalui observasi virtual dan kemudian dilanjutkan dengan wawancara. Batasan objek penelitian ini ialah Komunitas Mata Kita Regional Yogyakarta. Observasi virtual dilakukan pada laman resmi Narasi tv, postingan akun Instagram@matakita_yogya, @Narasi.tv, @najwashihab, dan @komunitasmatakita. Observasi virtual ini dilakukan dengan pertimbangan melihat bagaimana dialektika antara Komunitas Mata Najwa Yogyakarta, Narasi tv dan Najwa Shihab. Kemudian, juga menarik salah seorang informan dari Komunitas Mata Kita Yogyakarta ini keluar dari dunia virtual dan mengajaknya melakukan wawancara di dunia fisik. Ketika menggunakan pendekatan ini, perlu ditekankan bahwa setiap orang memiliki agenda politik dan etis sehingga diharuskan memilih siapakah yang tepat didengarkan dengan mempertimbangkan mempertimbangkan kriteria tertentu (Saukko, 2003). Pada kesempatan ini, peneliti mewawancarai informan yang berstatus sebagai leader baru komunitas Mata Kita Yogyakarta.

\section{HASIL DAN PEMBAHASAN}

Paparan pada subbab ini dimulai dengan menjelaskan komunitas Mata Kita. Kemudian, dilanjutkan dengan eksistensi komunitas tersebut dan bentuk ekspresi penggemar yang dilakukan. Pada bagian ini, dijelaskan bagaimana praktik sosial itu diproduksi dan direproduksi. Setelah itu, dilanjutkan pemaparan dinamika yang terjadi dalam interaksi antara komunitas Mata Kita dan Narasi tv. Dengan begitu, dapat dipahami relasi saling terkait antara fans, media, dan sosok yang diidolakan.

\section{Relasi antara Narasi tv, Komunitas Mata Kita, dan Najwa Shihab}

Mayoritas jawaban yang muncul ketika menanyakan alasan fans bergabung dengan komunitas Mata Kita ialah karena mereka mengidolakan Najwa Shihab, dan menganggap komunitas itu forum penggemarnya Najwa Shihab. Anggota komunitas Mata Kita Yogyakarta sudah mencapai 500 orang yang terwadahi dalam 3 grup WhatsApp. Mereka berasal dari latar beragam, mulai dari murid SMP, mahasiswa, hingga pekerja. Sebagian besar yang terlibat aktif berstatus mahasiswa. Interaksi mereka lebih sering dilakukan di media daring. Mereka biasanya mengadakan kopi darat untuk berkoordinasi secara fisik, dan juga nonton bareng Mata Najwa atau film (yang sesuai dengan spirit cinta tanah air) di bioskop. Pada momen tertentu, mereka menggarap event bersama dengan Najwa Shihab. Dari segi kepengurusan, selain terdiri atas pengurus tim inti, komunitas Mata Kita Yogyakarta juga memiliki tiga cluster kepengurusan seperti videografi, jurnalistik, dan sosial. 
Komunitas ini diharapkan menjadi forum bagi mereka yang terinspirasi oleh kebaikan Najwa Shihab supaya dapat mencontoh dan mengimplementasikannya dalam kegiatan positif ( $\mathrm{Za}$, Wawancara, 14 Desember 2018). Namun, menurut pengakuan informan, ketika sudah berada di forum, mereka jarang membicarakan kegiatan aktivitas terupdate dari Najwa Shihab dan lebih fokus mencontoh sikap idolanya tersebut pada tindakan. Mereka tidak dibebaskan membuat content untuk diunggah di media sosial, bahan event ataupun poster kegiatan. Sebaliknya, mereka harus menyesuaikan standar yang ditentukan oleh Narasi tv. Beberapa kali, mereka harus mendapatkan koreksian ketika tidak memenuhi standar yang disyaratkan.

Dalam perspektif linguistik, penamaan komunitas tersebut syarat dengan permainan bahasa. Menurut Saussure, (1959), hubungan antara penanda dan petanda itu bersifat arbitrer, mana suka. Berangkat dari pemahaman itu, permainan bahasa sangat mungkin dilakukan ketika Narasi tv menggunakan nama komunitas Mata Kita. Penggunaan kata "Mata" ini dipahami oleh fans merujuk ke program acara yang membuat sosok Najwa Shihab terkenal, yaitu "Mata Najwa”. Pemberian nama komunitas dengan "Mata Kita" seolah akan membuat fans memahaminya sebagai forum para fans "Najwa Shihab".

Narasi tv membangun statement bahwa ketika bergabung di komunitas, mereka akan memiliki kesempatan jalur fast track untuk bisa bertemu langsung dengan Najwa Shihab dalam suatu event. Fungsi fast track ini adalah mendapatkan tiket terlebih dahulu sebagai peserta dalam event tersebut. Namun, ini tidak terjadi serta-merta. Kelompok percakapan (WhatsApp) sering sepi karena jarang komunikasi. Hanya segelintir orang yang benar-benar mau turut dan aktif dalam kegiatan yang diselenggarakan oleh Mata Kita Yogyakarta. Efeknya, para anggota aktif juga kebingungan dengan kegiatan yang akan diselenggarakan. Karenanya, anggota yang telah bergabung akan selektif dan hanya melakukan kegiatan yang memenuhi orientasinya itu.

Bentuk ekspresi penggemar Najwa Shihab berbeda dengan bentuk fandom pada umumnya. Ini karena latar belakang Najwa Shihab sebagai tokoh dari dunia jurnalistik, dan berbeda dengan sosok idola fans pada umumnya yang berangkat dari dunia hiburan. Namun, layaknya fans pada umumnya, komunitas Mata Kita pun juga bersifat particular productive yang menurut Fiske dapat dikategorikan dalam tiga area: semiotic productivity, enunciative productivity, and textual productivity (dalam Fiske, 1992). Biasanya, dalam hal membangun makna (semiotic productivity), dirinya adalah penggemarnya Najwa Shihab. Mereka akan memunculkan tanda-tanda seperti mem-posting atau me-repost quote dari Najwa Shihab di akun postingan mereka. Namun, tidak banyak yang mengoleksi poster, memiliki buku karya Najwa Shihab atau berpenampilan mirip dengan Najwa Shihab.

Bentuk lain ekspresi fans adalah menonton tayangan Mata Najwa, dan acara live talkshow yang presenternya dibawakan oleh Najwa Shihab. Selain itu, membuat postingan dengan menampilkan kutipan dari Najwa Shihab atau mengupload fotonya bersama dengan Najwa Shihab yang kebetulan bisa bertemu secara langsung dalam suatu event. Secara enunciative productivity, mereka pada akhirnya memilih komunitas Mata Kita sebagai wadah antar-sesama penggemarnya Najwa Shihab. Mereka mengisi formulir untuk mendaftarkan dirinya sebagai anggota komunitas dan tergabung 
di dalam grup whatssapp. Untuk konteks textual productivity, mereka mewujudkan ekspresinya dalam bentuk pemikiran dan produktivitas melalui kegiatan-kegiatan yang ada di komunitas Mata Kita Yogyakarta. Mereka akan membuat event, memproduksi isi untuk tayang di Narasi tv, dan ikut berpartisipasi ketika ada eventnya Najwa Shihab berkunjung ke kota tempat mereka berdomisili.

Hal lain yang bisa ditelaah lagi ialah adanya ruang yang diberikan oleh Narasi tv yang menjadi wadah untuk komunitas Mata Kita berkarya. Jika menelusuri laman resminya, ada semacam slot khusus untuk memuat isi yang diproduksi oleh komunitas Mata Kita. Itulah tempat hasil konten dari komunitas yang telah dievaluasi dan direvisi oleh Narasi tv. Dalam kaitan ini, Narasi tv membangun wacana ketika karyanya berhasil masuk dan di-posting adalah suatu prestasi yang membanggakan karena telah melalui proses seleksi dan evaluasi.

Salah satu bentuk pencapaian yang diharapkan ketika bergabung dengan komunitas ini adalah menghilangkan batas antara dirinya sebagai fans dengan Najwa Shihab sebagai idola selayaknya mewujudkan hubungan pertemanan yang bisa saling chating-an dan berbalas komentar di sosial media (Za, Wawancara, 14 Desember 2018). Pada posisi inilah sebenarnya, bentuk hierarki fans itu terbentuk-selain dari struktur keorganisasian komunitas Mata Kita. Jika mengacu "The Forms of Capital" yang ditawarkan oleh Bourdieu (dalam J. Richardson, 1986), bentuk kapital yang terlihat dipraktikkan adalah social capital dan cultural capital. Pada konteks social capital, yang menjadi tolak ukurnya ialah ketika mereka memiliki kedekatan dalam kapasitas tertentu dengan tokoh idolanya. Di sanalah, ia merasa memiliki posisi yang lebih tinggi di komunitasnya. Mereka yang bisa mencapai itu adalah mereka yang biasanya pernah mendapatkan langsung projek talkshow bersama dengan Najwa Shihab dan menjadi moderator dalam event tersebut. Biasanya, dengan begitu, mereka bisa memiliki kedekatan dan akan lebih diingat oleh Najwa Shihab. Mereka bisa terus menjalin komunikasi via chat dan juga komentar di media sosial.

Seperti telah disinggung sebelumnya, fans tidak lagi memiliki kesempatan lebih untuk menjangkau tokoh idolanya jika dirinya tidak bergabung dengan komunitas Mata Kita. Ini karena Narasi tv memiliki otoritas dalam mengendalikan fandom. Padahal, fandom itu sebenarnya itu adalah ruang para penggemar (Jenkins, 2006). Fandom adalah tempat mereka sebagai penggemar bebas untuk belajar, berinteraksi, berkolaborasi yang menembus batasan kehidupan. Namun, Narasi tv menciptakan struktur supaya bisa terus menjaga khalayaknya, dan dapat menjadikan mereka sebagai sarana untuk mempromosikan Narasi tv.

Narasi tv terus membangun konstruksi sosial bahwa mereka harus merasa bangga bergabung dengan komunitas Mata Kita. Alasannya, karena Mata Kita adalah komunitas besar yang langsung dibawahi oleh Narasi tv. Lewat komunitas ini, mereka memiliki kesempatan yang lebih besar untuk mendapatkan pengalaman seperti di antaranya: "Mendapat informasi terkini mengenai program-program Narasi tv, menonton langsung siaran Mata Najwa di studio, terlibat dalam berbagai kegiatan Narasi Roadshow, diprioritaskan untuk magang di Narasi tv, memperoleh info lowongan bergabung ke Narasi tv, dan Dapat mengakses merchandise resmi Narasi tv (https://matakita.Narasi.tv/2018a). Kesempatan seperti itu akan sangat sulit didapatkan oleh mereka yang tidak bergabung dengan komunitas Mata Kata. 
Pemaparan di atas memberikan gambaran terkait telah distrukturkannya praktik sosial ekspresi penggemar Najwa Shihab. Struktur dibentuk melalui cara didirikannya Komunitas Mata Kita, dan membangun wacana bahwa komunitas itu menjadi jembatan untuk bisa lebih dekat dengan Najwa Shihab. Oleh karena itu, ketika ada yang bergabung menjadi anggota dalam komunitas itu, maka akan berhadapan dengan aturan (rules) yang ada. Secara umum, aturan yang diterapkan seperti turut berpartisipasi dalam beberapa kegiatan-baik yang langsung dari Narasi tv maupun kegiatan yang mereka inisiasi sendiri. Selain itu, mereka diminta terus memegang semangat anti korupsi, toleransi, dan partisipasi. Tidak hanya itu, struktur tersebut juga dipengaruhi oleh faktor sumber daya (resource) yang di sini akan dikelompokkan menjadi dua model sumber daya. Pertama, sumber daya yang bersifat material wujudnya dapat dirasakan seperti (1) sosok Najwa Shihab (dijadikan sebagai role model); (2) uang yang berhasil dikumpulkan anggota; (3) ruang berupa forum berbasis daring (website Resmi, Instagram Official, grup WhatsApp, Halaman Facebook, YouTube); dan waktu (dalam bentuk kesempatan menggarap event atau kesempatan bertemu langsung dengan Najwa Shihab). Kedua, sumber daya (resource) yang bersifat non materil di antaranya (1) kepercayaan; (2) energi; (3) loyalitas; (3) produktifitas; (4) kreatifitas; (5) skill/keahlian; dan (6) wawasan.

Fans dalam hal ini dianggap lebih dialogis ketimbang mengganggu (Jenkins, 2006) sehingga kehadiran penggemar Najwa Shihab di komunitas ini dapat diposisikan sebagai agen. Meskipun bergabung dengan Mata Kita tidak serta merta mendekatkan diri dengan sosok idolanya. Ini karena mereka mesti menjalani tahapan demi tahapan untuk bisa mendapatkan kapital sosial maupun kapital kultural- hingga akhirnya bisa lebih dekat dengan Najwa Shihab. Narasi tv di sini memiliki power berupa kedekatan dengan Najwa Shihab sehingga ia juga dapat mengontrol bagaimana agen terus aktif dan langgeng. Ada benarnya bahwa media bisa membangun struktur untuk menjadikan khalayak sebagai konsumen (Junaedi et al., 2017).

\section{Resistensi Anggota Komunitas Mata Kita}

Resistensi diposisikan sebagai upaya untuk men-delegitimasi yang dominan atau berkuasa, norma, serta perilaku mereka sehingga bisa melegitimasi alternatif terhadap itu. Resistensi ini dapat dipahami sebagai tindakan-tindakan kontroversial, baik skala kecil maupun besar. Ini karena ketika mereka melakukan perlawanan secara moral dan ideologis meskipun tidak secara material, mereka memiliki kontribusi untuk merusaknya (McGee, 2016).

Seiring berjalannya waktu, timbul kesadaran para leader bahwa mereka sedang "dimanfaatkan" oleh pihak Narasi tv. Kesadaran inilah yang kemudian melahirkan resistensi. Mereka merasa posisinya sebagai fans dimanfaatkan sebagai marketing-nya Narasi tv dalam berbagai kegiatan seperti kegiatan menyelenggarakan event dan pembuatan poster hingga memproduksi isi program untuk tayang di Narasi tv. Keseluruhan kegiatan tersebut dilakukan tanpa adanya bayaran atas jasa yang diberikan. Dengan demikian, Narasi tv memiliki keuntungan lebih dari aktivitas yang dilakukan oleh pihak Mata Kita karena di balik produktivitasnya ada energi dan waktu yang dikorbankan. Dalam praktiknya, ketika memproduksi isi mereka akan melalui tahapan evaluasi dan revisi sesuai dengan keinginan Narasi tv. Dalam hal ini, terdapat standarisasi isi baik secara konsep 
maupun teknis -meskipun secara peralatan tidak begitu.

Para anggota merasa bahwa selama ini tidak ada feedback baik yang didapatkan. Tidak ada reward, bahkan Narasi tv tidak banyak berbuat apa-apa di dalam grup. Sebaliknya, ketika Narasi tv memiliki program, mereka diharuskan aktif untuk menyebarkannya hingga mereka benar-benar menyadari bahwa sebenarnya posisi mereka dalam Mata Kita itu adalah sebagai fanbase Narasi tv, bukan sebagai fanbase-nya Mata Kita saja -khususnya yang mereka pahami di awal sebagai fanbase-nya Najwa Shihab. Mereka membaca bahwa sebenarnya Mata Kita itu dibentuk sebagai wadahnya bagi penonton Narasi tv. Pada akhirnya, secara serempak meninggalkan kepengurusannya di Mata Kita Yogyakarta ini.

Mereka kecewa dengan Narasi tv. Namun, mereka terlihat mendua (ambivalen) dalam melihat posisi antara Narasi tv dengan Najwa Shihab. Mereka melihat Najwa Shihab dan Narasi tv adalah dua hal yang berbeda. Padahal sebenarnya, jika dikaitkan lagi dengan pembahasan yang dijelaskan sebelumnya bahwa Najwa Shihab sendiri telah mengklaim Mata Kita ini adalah komunitas penontonnya Mata Najwa. Terlebih lagi, klaim Najwa Shihab memiliki power yang merupakan bentuk pemberian otoritas langsung dari sosok idola. Najwa Shihab merupakan salah seorang pendiri Narasi tv.

\section{Dialektika Komunitas Mata Kita yang Masih Bertahan}

Pembahasan sebelumnya sudah menjelaskan seputar tekanan fans yang didapatkan dari pihak Narasi tv sampai pada akhirnya mereka memutuskan keluar dari komunitas Mata Kita Yogyakarta. Pada pemaparan berikutnya, disuguhkan fenomena leader yang baru, dan masih bertahan di komunitas ini. Kasus ini dapat memperlihatkan bagaimana agen melakukan dialektika terhadap struktur sampai pada akhirnya memilih melakukan negosiasi daripada resistensi. Dalam kaitan ini, agen bisa melakukan negosiasi dan dapat mempengaruhi struktur. Ketika memposisikan khalayak sebagai agen, juga harus disadari bahwa khalayak merupakan sumber agency dalam sistem media. Suatu sistem media dapat mengalami perubahan dengan mempertimbangkan praktikpraktik khalayak media (Peruško et al., 2013).

Alasan yang ditemukan untuk bertahan sekiranya cukup menarik, yakni supaya bisa memahami lebih lanjut terkait ideologi apa yang ditanamkan oleh pihak Narasi tv kepada komunitas Mata Kita. Mereka mau "mendedikasikan" dirinya untuk menyesuaikan keinginan yang dicapai oleh Narasi tv. Pemahaman tentang kegiatan yang dilakukan di Mata Kita sebagai bentuk kegiatan produktif diterima oleh leader terbaru komunitas Mata Kita Yogyakarta. Salah seorang leader baru yang kerap disapa Za membenarkan bahwa Komunitas Mata Kita ini pada akhirnya bukanlah komunitasnya fans Najwa Shihab, melainkan Narasi tv. Meskipun pada dasarnya seluruh mereka yang ada di sini adalah fans Najwa Shihab. Namun, dirinya memiliki cara pandang yang agak berubah ketika memahami posisinya dalam komunitas ini. Za juga menyebutkan bahwa dirinya juga cukup bimbang ketika berada di jabatan ini. Dirinya kini menjadi ketua, tetapi belum memiliki struktur keorganisasian yang jelas karena ketika ia hendak memimpin forum diskusi dalam kegiatan kopi darat terkait pengembangan komunitas ini, setelah peninggalan leader terdahulu, kerab mendapatkan perlakuan yang tidak menyenangkan dari mantan pengurusnya.

Za mulai dengan semangat baru mengajak teman-temannya untuk kembali 
membentuk keorganisasian setelah ditinggal oleh leadernya terdahulu. Namun, tantangan terberat sekarang ialah anggota komunitas yang tingkat ekspresi fandom-nya tidak sebesar para leader terdahulu. Ia membenarkan klaim terkait tingkatan fans yang diucapkan oleh leader terdahulu, dan merasa agak sedikit kewalahan dalam pembentukan keorganisasian. Beberapa kali sudah pernah mengajak rekan-rekannya berkumpul dan masih gagal.

“Tanggung jawab" adalah kata sakti yang menjadi alasan bagi Za untuk tetap bertahan di komunitas ini. Ia juga mulai bernegosiasi dalam hal penerimaan dirinya terhadap komunitas Mata Kita Yogyakarta. Menurutnya, komunitas ini adalah tempat mereka untuk berkompetisi dan menggali pengalaman. Bahkan, ia memiliki semangat untuk mengubah pola pikir anggotanya dalam memahami dan memaknai komunitas ini. Dirinya berharap bahwa komunitas ini jangan hanya dianggap sekadar fanbase penggemarnya sosok Najwa Shihab, melainkan juga bisa dijadikan tempat melakukan banyak hal untuk terus berkarya.

Leader yang bertahan ini dikenal lebih bisa bersosialisasi dan membangun relasi baik dengan Narasi tv. Terlebih lagi, adanya event Playfest 2018 di Jakarta pada 24-25 November 2018 silam. Event ini adalah Festival pertama Narasi yang bisa dibilang sebagai event besar untuk mewadahi sekaligus menunjukkan eksistensi komunitas Mata Kita. Event ini menjadi wadah bagi Mata Kita secara keseluruhan untuk mewujudkan ekspresi dan eksistensi mereka lewat karyanya. Narasi tv menjadikannya sebagai ajang membentuk kompetisi antar-sesama mereka. Lewat event ini, $\mathrm{Za}$ berhasil melakukan pendekatan yang baik dengan
Narasi tv sampai bisa mempengaruhi kebijakan terhadap komunitas.

Perlakuan Narasi tv mulai berbeda antara leader terdahulu dengan yang sekarang. Leader sekarang ini memiliki kedekatan yang berbeda dengan Narasi tv. Bila para leader sebelumnya masih memiliki sekat yang menghambat proses interaksi mereka, leader sekarang ini malah lebih bisa menghilangkan batas sekat itu. Dalam hal pengadaan uang kas, misalnya, yang tidak dibolehkan pada kepengurusan sebelumnya. Ilustrasi ini tentu bisa diabstraksikan untuk menjelaskan perubahan struktur baru sebagai hasil dari proses negosiasi. Akibat praktik negosiasi yang dilakukan oleh leader sekarang, muncul kebijakan baru Narasi tv dalam menyikapi ini. Komunitas Mata Kita Yogyakarta akhirnya diperbolehkan untuk memiliki uang tabungan, tapi tidak diperbolehkan memiliki uang kas meskipun kebijakan ini cukup mendua (ambivalen). Namun, bisa dilihat bagaimana cara Narasi tv mencoba membedakan dalam cara membahasakan antara uang tabungan dengan uang kas. Padahal, konteksnya sama-sama dalam hal mengumpulkan uang, hanya menggunakan bahasa yang berbeda.

Contoh lain ialah diperbolehkannya memungut HTM (Harga Tiket Masuk) ketika komunitas Mata Kita Yogyakarta menggelar event. Keputusan ini akhirnya berhasil didapatkan setelah melakukan 'lobi-lobi' dengan pihak Narasi tv ketika mengikuti event Playfest 2018 di Jakarta. Za mencoba menjelaskan bahwa pada akhirnya uang itu akan kembali pada mereka yang menghadiri event tersebut. Pada awalnya, usulan tersebut ditolak, tapi melalui argumentasi akhirnya diperbolehkan. Narasi tv akhirnya membuat Narasi tv yang membolehkan komunitas untuk memungut uang tiket. 


\section{KESIMPULAN}

Penelitian ini menemukan bahwa Narasi tv sebagai televisi streaming, menjadikan relasi antara media dengan khalayak semakin kompleks. Media memiliki celah untuk membentuk dan menstrukturkan khalayak. Meskipun begitu ketika mendialogkannya dengan pendekatan strukturasi, bisa dilihat bahwa antara agen dan struktur itu bersifat dialektik. Penelitian ini menemukan bagaimana pemimpin komunitas Mata Kita yang berposisi (sebagai agen) bisa melakukan resistensi dan bahkan menjadikannya keluar dari struktur yang telah dibangun untuk kemudian berusaha membangun struktur baru. Meskipun begitu, cara mereka memandang Narasi tv dan Najwa Shihab cukup ambivalen. Mereka merasa kecewa dengan Narasi tv, tapi masih tetap mengidolakan sosok Najwa Shihab karena menurut mereka antara Narasi tv dengan Najwa Shihab adalah dua konteks yang berbeda. Selain itu, juga bisa terlihat bagaimana negosiasi yang dilakukan oleh leader yang baru. Hasil negosiasi itu adalah pihak Narasi tv mencoba melonggarkan beberapa kebijakan yang memudahkan anggota komunitas untuk tetap bisa produktif. Walaupun sudah menyadari dinamika komunitas tersebut, mereka masih tetap mencoba beradaptasi dengan Komunitas Mata Kita sembari terus mewujudkan ekspresi penggemarnya terhadap Najwa Shihab. Mereka memilih untuk tetap bertahan di sana dengan mempertimbangkan benefit yang didapatkan ketika bergabung dengan komunitas, sembari melakukan pendekatan yang lebih intens dengan pihak Narasi tv guna mempengaruhi struktur yang lebih longgar terutama dalam mengadopsi kepentingan mereka.

Penelitian ini lebih lanjut merekomen-dasikan pentingnya media mengubah cara pandangnya dalam melihat khalayak. Media harus melihat khalayak sebagai partisipan aktif, dan karena itu tidak lagi semata ditempatkan sebagai konsumen isi media yang pasif. Dalam konteks Narasi tv, cara pandang ini telah membuat komunitas melakukan resistensi dan bahkan keluar dari komunitas. Sebaliknya, pengadopsian atas berbagai proyek negosiasi baru atas kepemimpinan komunitas baru mampu menjamin kelangsungan komunitas secara lebih baik. Cara pandang khalayak aktif juga memungkinkan pembuatan program yang lebih partisipatif. 


\section{Daftar Pustaka}

A.S, M. F. (2017). "Invensi Di Balik Layar: Politik Penonton Streaming Setelah Televisi." Jurnal Penelitian Dan Pengabdian Masyarakat, 6(1).

Abdullah, Aceng, \& Lilis Puspitasari. (2018). "Media Televisi di Era Internet." Jurnal ProTVF, 2(1), 101110.

Anonim. (2018). "Najwa Shihab Ungkap Tantangan Jurnalis Perempuan,." Tempo.Co.

https://seleb.tempo.co/read/132266 4/najwa-shihab-ajak-musisi-nyanyirumah-kita-untuk-usir-kebosanan

Ashaf, \& Firman., A. (2006). "Pola Relasi Media, Negara, dan Masyarakat: Teori Strukturasi Anthony Giddens sebagai Alternatif.". Sosiohumaniora, $8(2), 205^{-218 .}$

Bennett, L. (2014). "Tracing Textual Poachers: Reflections on the Development of Fan Studies and Digital Fandom." Journal of Fandom Studies, 2(1), 5-20.

Boellstorff, T., Nardi, B., Pearce, C., \& Taylor, T. . (2012). "Chapter 1. Why This Handbook?," Ethnography and Virtual Worlds. Princeton University Press.

Enli, G., \& Syvertsen., T. (2016). "The End of Television-Again! How TV Is Still Influenced by Cultural Factors in the Age of Digital Intermediaries." Media Dan Communication, 4(3), 152-153.

Fiske, J. (1992). . "The Cultural Economy of Fandom," dalam The Adoring Audience: Fan Culture and Popular Media, ed. Lisa A. Lewis. Routledge.

Giddens. (1986). The Constitution of Society. Polity Press.
Guo, M. (2018). . "How Television Viewers Use Social Media to Engage with Programming: The Social Engagement Scale Development and Validation." Journal of Broadcasting \& Electronic Media, 62(2), 195-214.

Haryanto, I. (2014). "Kemunculan Diri dan Peran Pemilik Industri Media di Indonesia dalam Kerangka Teori Strukturasi Anthony Giddens." ULTIMACOMM, 6(2), 58-71.

Imran, H. A. (2016). "Penggunaan TV Streaming di Kalangan Masyarakat Perkotaan.” Jurnal Studi Komunikasi Dan Media, 2O(2), 119-137.

J. Richardson. (1986). "The forms of capital," dalam Handbook of Theory and Research for the Sociology of Education, ed. Greenwood.

Jenkins, H. (2006). Fans, Bloggers, and Gamers (Exploring Participatory Culure). New York University Press.

Jeong, Jae-Seon, Lee, S.-H., \& Sang-Gil Lee. (2017). "When Indonesians Routinely Consume Korean Pop Culture: Revisiting Jakartan Fans of the Korean Drama Dae Jang Geum.” International Journal of Communication, 11, 2288-2307.

Junaedi, F., Nugroho;, H., \& Wahyono, S. B. (2017). "Relasi Bonek dan Jawa Pos dalam Perspektif Strukturasi." Jurnal Komunikator, 9(2), 123-138.

McGee, R. (2016). "Power and Empowerment Meet Resistance: A Critical, Action-Oriented Review of the Literature." IDS Bulletin, 47(5), $103-118$. https://doi.org/10.19088/19682016.170 
Mosco, V. (2009). The Political Economy of Communication. SAGE Publications.

Mulyana, A., Briandana, R., \& Dwi Anggraini Puspa Ningrum. (2019). "Social Construction Fandom as Cultural Industry Marketing of JKT 48 Fan Group." International Research Journal of Business Studies, 12(3), 257-266.

No Title. (2018a). https://matakita.Narasi .tv/

No Title. (2018b). https://www.instagram. $\mathrm{com} / \mathrm{p} / \mathrm{Bdr} \_$w3HQ3Q/

No Title. (2020). https://www.instagram. com/p/BYbByR8hIta/

Nugroho, Y., Amalia, D., Nugraha, L. ., Siregar, M. F., Esti, K., \& Putri, D. A. (2015). Televisi Indonesia: Dinamika struktur dan khalayak. Centre for Innovation Policy and Governance, University of Manchester, Ford Foundation Indonesia.

Otmazgin, Nissim, \& Lyan, I. (2013). "Hallyu across the Desert: K-pop Fandom in Israel and Palestine." Journal of Cross-Currents: East Asian History and Culture Review, 9, 68-89.
Pearson, R. (2010). "Fandom in the Digital Era." Journal of Popular Communication, 8(1), 84-95.

Permana, Rangga, Saptya, M., Abdullah, A., \& Mahameruaji, J. N. (2019). "Budaya Menonton Televisi di Indonesia: Dari Terrestrial Hingga Digital.” Jurnal ProTVF, 3(1), 101110.

Peruško, Z., Vozab, D., \& Antonija Čuvalo. (2013). Audiences as a Source of Agency in Media Systems: PostSocialist Europe in Comparative Perspective. Mediální Studia / Media Studies, 2, 137-154.

Pratama, \& Putra, B. (2018). "Strukturasi Komunikasi Internal dalam Praktik MediamRelations di Dalam Industri Media." INFORMASI Kajian Ilmu Komunikasi, 48(1), 2502-3837.

Saukko, P. (2003). Doing Research in Cultural Studies: An Introduction to Classical and New Methodological Approaches. SAGE Publications.

Saussure, F. de. (1959). Course In General Linguistics, trans. Philosophical Library.

Silva, Da, E. C., \& Casas, A. L. Las. (2017). "Sport Fans as Consumers: an Approach to Sport Marketing." British Journal of Marketing Studies, 5(4), 34-46. 
Jurnal komunikasi, Volume 14, Nomor 2, April 2020, Hal 105-118 